\title{
PLAN FOR ACTION AGAINST THE DETALIED SEED ${ }^{1}$
}

\section{U. GRANT KEENER}

Universidade Federal do Paraná

certainly sounds like "the life" with all that time off. I often think I should have gone into another line of ...

\section{I \\ MAN THE PUMP}

Man the pump and hydrophobe engages fire Ardent in his cells a slow combustion (A form of trust in rust-tomorrow's dust) Soar smoking flamebird's dart from inglenook Conspiring for higher with the midle air, Unheared but as a roar gone by the book. A microscope (thing-thing par excellence) Shows cells metabolize with brisk indifference To their coming urbane subdivision. The gravity that cinders us to earth Permits our play both now and at the close. We watch the living fire upon the stages And waver, now for it, now for the hose.

\section{THE FIRST PERSON}

Prefend me no pretends that there's no 1 Discerning fit from fact-the daily muse To strip the veils from why as though I choose.

1 Students registered for the full program will be required to conform to the rules laid down in this catalog. 
I stand here like saltpeter on a rock

Commanding exalted metre in the dock.

An unregarding fragment (general mirth)

Of bright particular that fell to earth.

You claim these trophes don't clarify a motive?

$T$ pray you then,

Write me as reluctant to be votice.

They'd never buy a Trojan horse again.

I said at the time, what's it there for? Why's

it there. You know? But no one listens. I

know, now it's over it's easy enough to

say, but famous last words. Maybe it's insanity

to insist everything has got to have a meaning,

but it's better than assuming they don't. You

know? But no one listens.

I can't agree to stand here and let fear

Run down my leg and off on the mocadam.

What 1 have in mind is more

Like God's scentilla spartking down to Adam.

Engendering (two-way mirrows in a door)

Humanitarianoid concern

As turrets lathe quick triggers out of comment.

Or is it those who cannot turn must learn

To gladly teach the matter of the moment,

The hook of speech a bee-buzz in the bonnet?

Such crooks are orbit patterns to a comet.

They'd never buy a Trojan horse again.

\section{GAME THEORY}

This lacks specific gravity? The task

Is not strike through commemorative masque.

This coupling stifles yet we're well aware Something there is that beckons us to pair, (It entails a break to stop and ask).

Something there is rocks our best intentions.

With a hmm and a hrmph and a hoo ha ha,

Announcing, observe, come to our conventions!

With a hey nonny know a brouhaha.

Yet how tell a maskarah from a casque? 
Say that in the summa on a day, for sport

I lockstepped to the customary place,

Then wedded serve and wait as in the ode

The man wrote on his blindness. No disgrace

In his case, nor need we impute a code

Of innermost depravity. We ask

No such immunity in our community:

I mention this who'd thought that love might be

The way to justify the four-square court.

Is love the goose-egg end of having failed?

And is the shepherd crook a lonely basque?

Why all these shepherds?

We might try a sheep.

\section{CONVENTION}

and of course there's something doing every minute: meetings and get-togethers, at which ideas are exchanged. I once exchanged ideas with a total stranger and was a near-idiot until 1 could effect a new exchange. Never got my own back.

Why all these shepherds? I had not thought They had brought so many silken lines and silver hooks Who have and had their peer and wrought Along the tattered seaming ideas lurk, And night looks in at the end, Gleid with fears and sycophancy and sin-

Cerity beatified by ginger

And other small beer.

Why so many shepherds here?

Chark me this circle. We'll pretend the world outside will stary there. Look:

If we're to figure form, a questtion-marked-shaped crook or dirk Will catch more flies than netting car,

To clarify the seam to man.

You're treading on a shepherd's finger, Jack. 
Image in sieve a rat without tail,

Carry it high in your pre-frontal section.

Comes master with tiger in this direction,

But outside the chalk, beyond the pale.

The pale ale, there's the brew (ha ha). Your double

It's the single vision casues the trouble.

Take them up in spring to the highes! grass of all, They'el fatten, if that's living, in the bottom, come the fall.

\section{SUMMA IS ACUMEN LAUDE}

Ring the welkin, deck the hall

For pastor and for pastorale.

The master gardner prunes against the fall.

(I have sat at bay windows looking out for number one and missed him time and again. I would have made a grand jury if I had found myself in was it Queens? - wherever it happened. By what sobsistery can newshens and hawks pretend outrage that not one of thirty-eight shot out a helping hand? How could they speak or separate the screen. Is the seventy-two inch realer than the seventeen? Seven-reeler? Or just bigger? An impossible ratiocination. And is separation desirable? Ghosts?

Flopover? Here's to the screen. God blesser. I sometimes think that aye should have gone...)

The boxingday twins and Helen, their schwester

Needed a fourth and they got Clytemnestra.

Feathered glory, loosened thighs.

Hardly the thing to pastorize.

Ring the welkin, deck the hall

For pastor and for pastorale.

\section{TO MEET D. THOMAS}

Stick to the conrete, (they told me, that's the only thing worth knowing. I didn't want to argue, they meant best, and even now I don't say they 
were wrong. But I stuck to it, and all I say is unless I just leave my shoes there like in Grauman's Chinese and walk away barefoot, how do I eat?

Invited for that last Sunday though I couldn't know it (Count no man happy till you check with Solon) I went of course, best-suited in buckram to meet him And arrived lock stock and barreled at Beekman Place, Beheld cherries safe in Manhattans and saw across the room The famous head and rump, dogging it among

The Pharoah's daughters of the island. Georgia led me Ring in nose to where he held forth or perhaps a fifth, Forgotten serviette in half-raised hand Like lambchop paper. Garniture of fruit

Was briefly seen upon his lips and then, "High ham, the long pig, gentlemen".

We gaping round, our sallies very sharp, Were nothing loath, fell too.

I broached him, found him tender

To a younger and less gifted man.

"Well done", someone observed, not quite regretting.

We made a meal. It was a mixed bag, opened, seasoned, meet.

We were to make him on the Thursday,

Georgia, Oscar, John and I,

In the garden that never quite seems

To overlook the river and yet won't recognize it.

We recognized the need to wake him, see?

But he had gone his progress through our:

Praise!

We kill our poets cubbing nowadays.

\section{VERMIFORM FOOTNOTE}

I said, what's it doing there. It must mean something.

But I've been speaking like this all my life. You know? In prose? No one listens unless it sounds bardic. But it takes a special knack. And it helps if you're a shepherd or something like that. Even a fisherman. Animal totems are strong, don't tell me different. Sugar was made before tongs. Ask any Chinaman. 
The big fall day dawned crisp and clear,

The plunk of pigskin filled the air, With a raw and a hip and a ray.

The spring day overcame the night,

The sheepskin hoof with cleave the light

With a baa and a fresh B. A.

Granted the past is orloge, could we but know it, How to tell the proem from the proet?

Provide them with balance, perspective and surd, If they miss it we must fail them, a squinting, two-edged word.

Turn them gently out in sprin to the highest grass of all, They'll batten, down their hatches, in the bottom, come the fall. 